\title{
THE EFFECT OF MUROTTAL QUR'AN ON MENSTRUAL PAIN IN NURSING STUDENT OF UNIVERSITAS NAHDLATUL ULAMA SURABAYA
}

\section{Yurike Septianingrum $^{1 *}$, Nety Mawarda Hatmanti ${ }^{1}$, Andikawati Fitriasari ${ }^{1}$}

${ }^{1}$ Faculty of Nursing and Midwifery, Universitas Nahdlatul Ulama, Surabaya, East Java 60115 , Indonesia

*Correspondence:

Yurike Septianingrum

Email: yurikesepti1209@unusa.ac.id

\begin{abstract}
Background: Primary dysmenorrhea is menstrual pain that is found without significant abnormalities in genital organs. More than $50 \%$ of women experience primary dysmenorrhea and 15\% experience severe pain. Most women never have their primary dysmenorrhea examined by a doctor or midwife, arguing that this is something natural, even if this condition is left unchecked, symptoms of endometriosis will emerge that can affect women's fertility.

Objectives: The purpose of this study was to examine the effect of Murottal Qur'an on menstrual pain in nursing students of UNUSA. Methods: This study was an experimental research approach with pre-test post-test design at UNUSA. Research subjects of this study was recruited using simple random sampling who was included inclusion criteria. Research subjects in this study was of 32 students who were then divided into two groups, 16 students into intervention group and 16 students into control group. Data were collected by using observation with VAS. Data were analyzed by using sign test and Mann-Whitney U test.

Results: The results showed that: 1) Score of VAS in intervention group post testwas less than pre test $(\mathrm{p}=0,000), 2)$ Score of VAS in intervention group was less than control group $(\mathrm{p}=0,006)$.

Conclusion: Murottal Qur'an could reduce menstrual pain in nursing student of UNUSA. Further research, is expected that Murottal Qur'an can be compared with music therapy to reduce menstrual pain.
\end{abstract}

Key words: Menstrual pain, Murottal Qur'an, primary dysmenorrhea.

\section{INTRODUCTION}

Menstruation is a physiological change in a woman's body that occurs periodically and is influenced by reproductive hormones. Menstruation usually occurs every month between teens to menopause (Aden, 2010). Pain that occurs during menstruation is caused by the release of the uterine wall (endometrium) accompanied by bleeding (Chang, 2009). Primary dysmenorrhea is menstrual pain that is found without significant abnormalities in genital organs. More than $50 \%$ of women experience primary dysmenorrhea and $15 \%$ experience severe pain. Dysmenorrhea that occurs in final year college students can lead to difficulty for them to concentrate on doing thesis (Sari et al, 2015). Most women have never seen primary dysmenorrhea experienced by a doctor or midwife, arguing that this is something natural, they only drink herbal medicine, rest, and sleep 
to reduce dysmenorrhea, even if this condition is left, symptoms of endometriosis can occur which can affect fertility woman (Novia \& Puspitasari, 2008). The incidence of dysmenorrhea in the world is very large, on average more than $50 \%$ of women in each country experience dysmenorrhea. In the United States, menstrual pain is found in $30-70 \%$ of women of reproductive age, and 60-70\% of unmarried adult women. Research in Sweden found that $30 \%$ of industrial workers declined their income due to menstrual pain. Abnormalities occur in 60 $70 \%$ of women in Indonesia with $15 \%$ complaining that their activities are limited due to dysmenorrhea (Novia \& Puspitasari, 2008). Handling of dysmenorrhea can be done in two ways, namely pharmacological and non-pharmacological therapy. Nonpharmacological therapies that have been carried out as an effort to overcome dysmenorrhea include warm compresses, Mozart therapy, rest, herbal consumption, acupuncture, acupressure, exercise, relaxation and spiritual therapy, one of which is murottal quran. Murottal quran is one music that has a positive influence on its listeners (Muhidin, 2016).

The results of a preliminary study on UNUSA Nursing undergraduate students showed that $51 \%$ had moderate menstrual pain, $12 \%$ had severe menstrual pain, and $37 \%$ had mild menstrual pain. Other complaints faced during menstruation were $62 \%$ saying emotions were unstable, $11 \%$ dizzy, $4 \%$ nausea vomiting, $5 \%$ back pain, and the rest others. Actions taken when dealing with menstrual pain, as much as $59 \%$ rest, $18 \%$ leave it alone, $6 \%$ take analgesics / pain relief, 3\% drink herbal medicine, and the rest others. Pain management is needed to deal with menstrual pain. One of the nonpharmacological therapies to reduce menstrual pain is Murottal Qur'an (Muhidin et al, 2016). The distraction technique with Murottal Qur'an can stimulate delta waves that cause listeners to be calm, calm and comfortable (Wahida, 2015). Until now, the influence of Murottal Qur'an on menstrual pain in female nursing students at the Nahdlatul Ulama University in Surabaya has not been explained.

\section{METHODS}

Study Design

The design of this study was experimental with the design of the PreTest and Post-Test control group design. The distribution of samples in both groups was determined randomly.

Setting

This research was conducted in the Undergraduate Nursing Study Program, Faculty of Nursing and Midwifery, Nahdlatul Ulama University, Surabaya, East Java Province, Indonesia.

\section{Research Subject}

The population in this study were all final year college students in the Undergraduate Nursing Study Program, Faculty of Nursing and Midwifery, Nahdlatul Ulama University, Surabaya, East Java Province, Indonesia who met the inclusion criteria: 1) primary dysminore, 2) age 17-20 years, 3 ) normal menstrual cycle (21-35 days), 4) menstrual period 3-7 days, 5) no menstrual abnormalities, 6) willing to be studied and signed informed consent. Exclusion Criteria: 1) students who take pain-lowering drugs or herbs, 2) get married, 3) get pregnant. Drop Out Criteria: 1) Students who decide to take painlowering drugs before evaluating pain, 2) there is a request to stop the intervention of the research subjects before the intervention is truly done. The research subjects were taken randomly according to the sample size formula of 32 respondents. The research subjects were then divided into two random groups: 16 respondents entered the treatment group (got murottal Qur'an treatment) and 16 respondents entered the control group (received deep breath therapy to reduce menstrual pain). 


\section{Instruments}

The instrument of this study was the observation sheets Visual Analog Scale (VAS).

\section{Data Analysis}

The data that has been collected is then processed with spss using the Sign test and Mann-Whitney U Test.

\section{Ethical Consideration}

This research has gone through an ethical test from the Nahdlatul Ulama University of Surabaya and obtained permission from National Unity and Politics of Surabaya Regency.

\section{RESULTS}

Characteristics of Respondents by Age

Table 1. Distribution of Frequency of Respondents by Age in the Undergraduate Nursing Study Program, Faculty of Nursing and Midwifery, Nahdlatul Ulama University, Surabaya, East Java Province, Indonesia $(\mathrm{n}=32)$.

\begin{tabular}{cccc}
\hline Age (Years) & Total & Percentage (\%) \\
\hline 17 & 2 & 6.25 \\
18 & 14 & 43.75 \\
19 & 12 & 37.50 \\
20 & 4 & 12.50 \\
\hline Total & 32 & 100.00 \\
\hline
\end{tabular}

Sources: Primary Data of Questionnaire, 2018

Based on table 1, it was found that the characteristics of respondents based on age were majority 18 years old, as many as 14 respondents $(43.75 \%)$.

Characteristics of Respondents by Age of Menarche

The results of study on table 2 found that the characteristics of respondents by age of menarche was 12 years old, as many as 10 respondents $(31.25 \%)$.
Table 2. Distribution of Frequency of Respondents by Age of Menarche in the Undergraduate Nursing Study Program, Faculty of Nursing and Midwifery, Nahdlatul Ulama University, Surabaya, East Java Province, Indonesia $(\mathrm{n}=32)$.

\begin{tabular}{ccc}
\hline $\begin{array}{c}\text { Age of Menarche } \\
\text { (Years) }\end{array}$ & Total & Percentage (\%) \\
\hline 10 & 3 & 9.375 \\
11 & 5 & 15.625 \\
12 & 10 & 31.250 \\
13 & 8 & 25.000 \\
14 & 6 & 18.750 \\
\hline Total & 32 & 100.000 \\
Sources: Primary Data of Questionnaire, 2018 \\
VAS Pre-Test and Post-Test $\quad$ Value \\
Diagrams in the Treatment Group
\end{tabular}

Figure 1. VAS Pre-Test and Post-Test Value Diagrams in the Treatment Group.

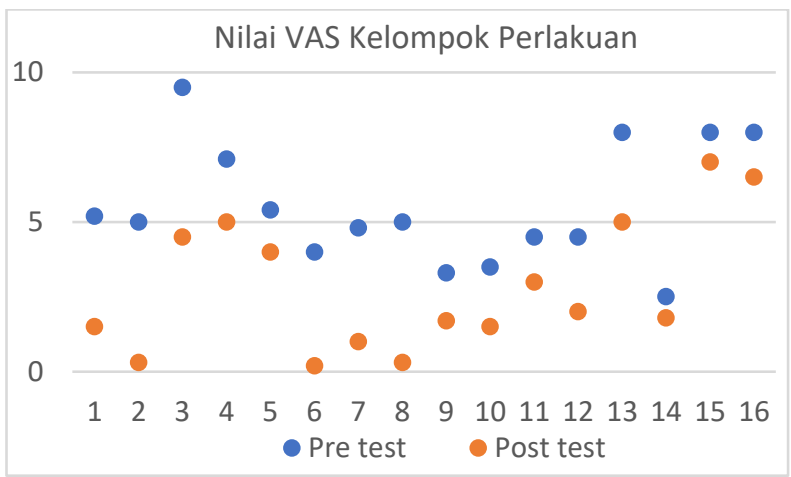

Sources: Primary Data of Questionnaire, 2018

The results of the study on Figure 1 found that all female students $(100 \%)$ experienced a decrease in the VAS scale after being given an Ar-rahman murottal Qur'an intervention for 15 minutes. 
VAS Pre-Test and Post-Test Value Diagrams in the Control Group

The results of the study on Figure 2 found that the majority of students in the control group experienced a decrease in VAS scale after 15 minutes of deep breathing relaxation.
Figure 2. VAS Pre-Test and Post-Test Value Diagrams in the Control Group.

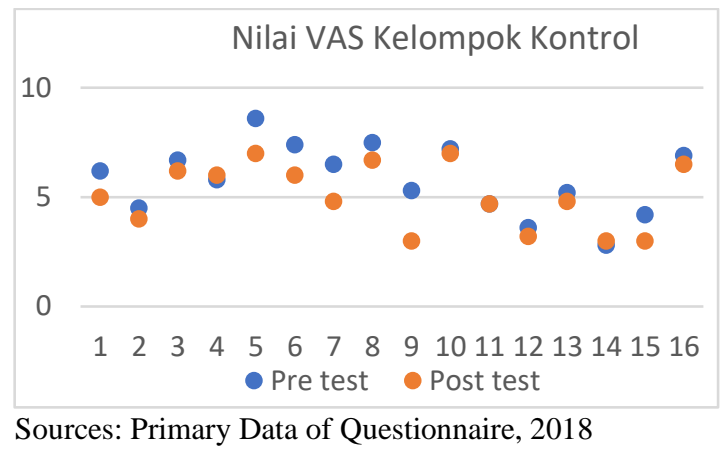

VAS Post-Test Value Diagrams in the Treatment Group and Control Group

Figure 3. VAS Post-Test Value Diagrams in the Treatment Group and Control Group.

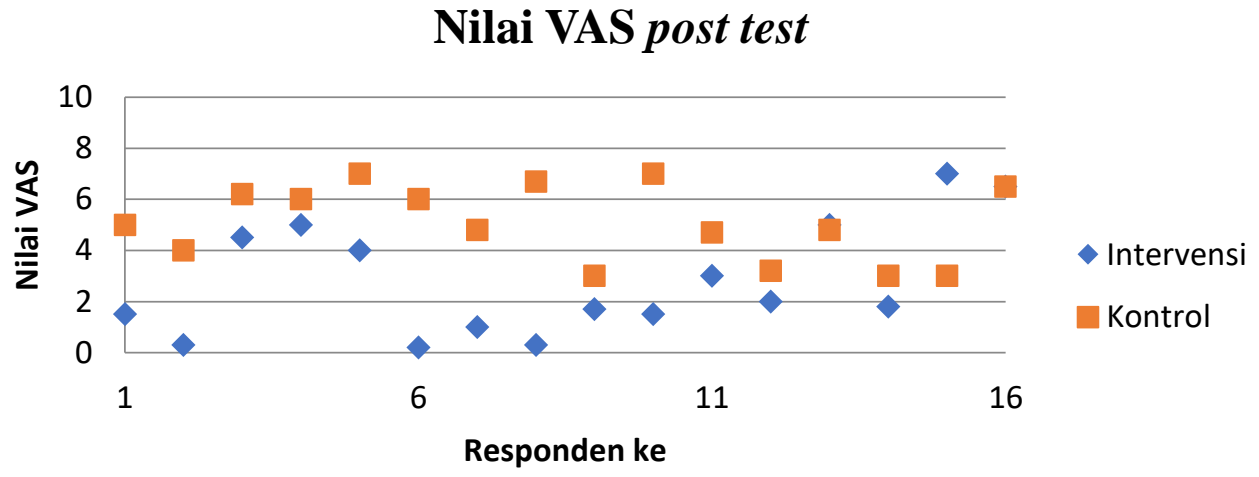

Sources: Primary Data of Questionnaire, 2018

The results of the study on Figure 3 found that VAS Post-Test value in the intervention group was in the range of 0.2-5, while in the control group it was in the scale of 3-8. VAS values in the intervention group were lower than the control group. This shows that Murottal Qur'an therapy can reduce menstrual pain.

Analysis of VAS Value Differences between Treatment and Control Groups (Pre-Post Test) on Students in the Undergraduate Nursing Study Program, Faculty of Nursing and Midwifery, Nahdlatul Ulama University, Surabaya, East Java Province, Indonesia

Based on table 3, it was found that the results of the analysis with the Sign-test in the treatment group had significant differences in menstrual pain before and after the Murottal Qur'an intervention was given with $p=0.00(\alpha<0.05)$. This shows the murottal Qur'an Ar-rahman's letter given for 15 minutes can reduce menstrual pain in female students of the Nursing undergraduate program at Nahdlatul Ulama University, Surabaya. In the control group there were significant differences in menstrual pain before and after given deep breath relaxation with $p=0.007(\alpha<0.05)$. This shows that deep breath relaxation given to the control group for 15 minutes is also able to reduce menstrual pain in female 
nursing undergraduate students program at the Nahdlatul Ulama University, Surabaya.

Table 3. Analysis of VAS Value Differences between Treatment and Control Groups (Pre-Post Test) on Students in the Undergraduate Nursing Study Program, Faculty of Nursing and Midwifery, Nahdlatul Ulama University, Surabaya, East Java Province, Indonesia (n $=32$ ).

\begin{tabular}{cccc}
\hline Groups & Pre-test & Post-test & $\boldsymbol{p}$-value \\
\hline Treatment & $(5.5187 \pm 2.00806)$ & $(2.8313 \pm 2.22253)$ & $p=0.000$ \\
Control & $(5.8188 \pm 1.58796)$ & $(5.0563 \pm 1.48188)$ & $p=0.000$ \\
\hline
\end{tabular}

Sources: Primary Data of Questionnaire, 2018

Analysis of VAS Value Differences between Treatment and Control Groups (Pre-Post Test) using the Sign test and Mann-Whitney $U$ Test on Students in the Undergraduate Nursing Study Program, Faculty of Nursing and Midwifery, Nahdlatul Ulama University, Surabaya, East Java Province, Indonesia

Table 4. Analysis of VAS Value Differences between Treatment and Control Groups (Pre-Post Test) using the Sign test and Mann-Whitney U Test on Students in the Undergraduate Nursing Study Program, Faculty of Nursing and Midwifery, Nahdlatul Ulama University, Surabaya, East Java Province, Indonesia (n $=32$ ).

\begin{tabular}{lrr}
\hline & Pre VAS & Post VAS \\
\hline Mann-Whitney U & 111.500 & 55.500 \\
Wilcoxon W & 247.500 & 191.500 \\
Z & -.622 & -2.738 \\
Asymp. Sig. (2-tailed) & .534 & .006 \\
Exact Sig. [2*(1-tailed Sig.)] & $.539^{\mathrm{a}}$ & $.005^{\mathrm{a}}$ \\
\hline Sources: Primary Data of Questionnaire, 2018 &
\end{tabular}

Based on table 4, it was found that there were significant differences in VAS values in the treatment and control groups, namely $\mathrm{p}=0.006(\alpha<0.05)$. Based on the results of these studies indicate that the Murottal Qur'an can reduce menstrual pain on Students in the Undergraduate Nursing Study Program, Faculty of Nursing and Midwifery, Nahdlatul Ulama University, Surabaya, East Java Province, Indonesia.

\section{DISCUSSION}

Menstrual Pain Before and After Murottal Qur'an Intervention was Given in the Treatment Group

Primary menstrual pain occurs, if there is no organic disease, usually from the sixth month to the second year after menarche. Menstrual pain will disappear at the age of 25 years or after a woman is pregnant and has a vaginal delivery. Some women, heat (hot compresses or hot showers), massage, distraction, physical exercise, and sleep are sufficient to relieve primary menstrual pain (Bobak, 2005). Primary menstrual pain almost always occurs during the ovulation cycle (ovulatory cycles) and usually appears within a year after the first menstruation. In classic primary menstrual pain, pain begins just before menstruation and persists or persists for 1-2 days (Anugoro, 2011). Menstrual pain faced by female students is primary dysmenorrhea, because from the preliminary results all study subjects did not experience abnormalities during menstruation, but some stated that menstruation is sometimes irregular. Fair irregular menstruation is faced by young women because reproductive hormones such as estrogen are not yet stable.

The pain is described as spasmodic and spread to the rear (back) or upper thigh or the middle. In epidemiological studies around 70-90 percent of menstrual pain cases occur during adolescence. Associate with general symptoms, such as the following: 1). Malaise (feeling unwell), 2). Fatigue, 3). Nausea and Vomiting, 4). Diarrhea, 5). Lower back pain, 6). Headache, 7). Sometimes it can also be accompanied by vertigo or a falling sensation, feeling anxious, anxious, and falling unconscious (Anugoro, 2011). The results of the preliminary study showed that 
the pain felt was also accompanied by other complaints. Other complaints faced during menstruation were $62 \%$ saying emotions were unstable, $11 \%$ dizzy, $4 \%$ nausea vomiting, $5 \%$ back pain, and the rest others. Most of them deal with pain just by resting or letting go, but they also say it turns out that menstrual pain still interferes with their activities.

The effect of listening to murottal AlQur'an is to calm, relax even if only one time is heard. It is seen from the EEG recordings showed Murottal therapy Qur'an dominated by the rise of an average of $63.11 \%$ delta waves, these waves arise at the right and left frontal areas of the brain. Someone who listens to Murottal Al-Qur'an in very calm conditions even as a picture of someone sleeping inside (Abdurrochman et al, 2008).

Sign test results showed that there were significant differences in menstrual pain before and after the Murottal Qur'an intervention was given. The results of these studies indicate that the Murottal Qur'an is able to reduce menstrual pain in female students. The results of interviews with several research subjects, murottal Qur'an surah Ar-Rahman which they listened for 15 minutes was able to divert the mind (distraction) from pain, there were even students who memorized the Surah ArRahman and their translations so that they could absorb the contents of Surah ArRahman.

The chanting of the verses of the Qur'an in murottal Ar-Rahman has a relaxing effect on the body because the rhythm is constant, regular, and there are no sudden changes and the tone is low. Murottal physically contains human sound elements that can stimulate the body to reduce stress hormones, activate endorphins naturally, increase feelings of relaxation, divert attention from fear, anxiety and tension, improve metabolism so as to reduce blood pressure and slow breathing, pulse and brain wave activity. The deeper or slower breathing rate is very good for causing calm, emotional control, deeper thinking and body metabolism (Wisudawati, 2014). Abdurrochman (2008) explains that the brain wave component of stimulants in music therapy and stimulants of the Al Quran (Murottal) have similarities which are dominated by delta waves. The existence of these delta waves indicates that a person's condition is very relaxed, so that the stimulant of the Qur'an (Murottal) can provide peace, tranquility and comfort for a person.

\section{Menstrual Pain in The Treatment and Control Groups}

Most of the research subjects felt menstrual pain on a VAS scale on a scale of 5 , indicating menstrual pain that they felt was moderate to severe pain. Primary dysmenorrhea is menstrual pain that is found without significant abnormalities in genital organs. More than $50 \%$ of women experience primary dysmenorrhea and $15 \%$ experience severe pain. One of the factors that cause dysminorrhea is stress. Early semester students have high stress levels because they are required to adapt to the campus environment and quite a lot of tasks. This condition makes female students susceptible to primary disminore. There is a student disminore which can make it difficult to concentrate in the lecture process (Sari et al, 2015). Menstrual pain is almost always felt by young women, especially female students, but they are often considered reasonable so that this incident was never reported to health workers. If this is allowed, it will disrupt their activities even in the learning process on campus. Good pain management is needed to overcome menstrual pain.

The results of the Mann-Whitney analysis showed that there were significant differences in menstrual pain in the treatment group. This shows that the Murottal Qur'an is able to reduce menstrual pain when compared to the control group who get deep breathing relaxation. The results of interviews with female students, 
they enjoyed the chant of Ar-Rahman letters that they listened to through mp3 so they were able to distract the menstrual pain they felt. Religious therapy included in it is murattal therapy. Murratal therapy is therapy using Al-Quran reading which is a religious therapy where a person is heard reading verses of the Koran for several minutes or several hours so that it has a positive impact on one's body. The results of the research that have been conducted by Al-Qadhii (1997) in Riyadhi (2014), that there is an influence that occurs from listening to the Murattal of the Qur'an in the form of changes in muscle electrical current, changes in skin capture power. These changes indicate a relaxation or decrease in the reflective nerve tension which results in the relaxation of arteries and the addition of blood levels in the skin, accompanied by an increase in skin temperature and a decrease in the frequency of heartbeat (Siswanto et al, 2011).

Another study that proves murottal Qur'an can also reduce pain is the Handayani (2014) study which shows that Murottal Qur'an Therapy can reduce labor pain in the first active phase in primigravida in accordance with Al-Kaheel (2011), who said that the Qur'an the one that is played will have a relaxing effect of $65 \%$. AlQur'an reading therapy has been shown to activate body cells by converting sound vibrations into waves captured by the body, reducing pain receptor stimuli and arousing the brain to secrete endogenous natural opioid analgesics. This opioid is permanent to block pain nociceptors.

\section{CONCLUSION}

The provision of Murrotal Qur'an for Ar-Rahman for 15 minutes on the Students in the Undergraduate Nursing Study Program, Faculty of Nursing and Midwifery, Nahdlatul Ulama University, Surabaya, East Java Province, Indonesia during menstruation can reduce menstrual pain.

\section{SUGGESTIONS}

Murottal Qur'an therapy is expected to be one of the non-pharmacological therapies to reduce menstrual pain. Good pain management is needed by students so that menstrual pain does not interfere with teaching and learning activities on campus and other activities. Future studies are expected to be able to compare the murottal therapy of the Qur'an with music therapy to reduce menstrual pain.

\section{REFERENCES}

Abdurrochman, A., Wulandari, R. D., \& Fatimah, N. (2007). The Comparison of Classical Music, Relaxation Music and The Qur'anic Recital: an AEP Study.

Aden, R. (2010). Ketika Remaja dan Pubertas Tiba. Yogyakarta: Hanggar Keraton.

Alfisah, Fitri. (2016). Teknik Effleurage (Massage) sebagai salah satu intervensi keperawatan untuk mengatasi masalah gangguan rasa nyaman pada An. A pada keluarga Bapak P dengan disminore. Accessed on June 15, 2017 from http://lib.ui.ac.id/file?file=digital/2016 -11/20434752-PR-

Fitri\%20Alfisah.pdf.

Al-Kaheel, A. (2011). Al-Qur'an The Healing Book. Jakarta: Tarbawi Press.

Anurogo, D. \&Wulandari, A. (2011). Cara Jitu Mengatasi Nyeri Haid. Yogyakarta: ANDI Yogyakarta.

Bobak, Lowdermilk, \& Jensen. (2005). Buku Ajar Keperawatan Maternitas. Jakarta: Penerbit Buku Kedokteran EGC.

Chang, Esther. (2010). Patofisiologi Aplikasi pada Praktik Keperawatan. Jakarta: EGC.

Handayani R., Fajarsari D., Asih DR. (2016). Pengaruh Terapi Murottal Qur'an terhadap Penurunan Intensitas Nyeri Persalinan dan Kecemasan dalam Persalinan Primigravida Kala I Fase Aktif di RSUD Dr. Margono 
Soekarjo Tahun 2014. Accessed on June 13, 2017 from http://ojs.akbidylpp.ac.id/index.php/Pr ada/article/viewFile/147/135.

Kartika IR. (2015). Pengaruh Mendengar Murottal Al-Qur'an terhadap Penurunan Intensitas Nyeri Pasien Pasca Operasi Apendisitis. Accessed on June 15, 2017 from http://repository.unri.ac.id/xmlui/bitstr eam/handle/123456789/7471/

Artikel\%20Imelda\%20R.pdf?sequenc $\mathrm{e}=1$.

Muhidin dkk. (2016). Pengaruh Murottal Ar-Rahman terhadap Nyeri Disminore pada Remaja. Jurnal Keperawatan Madiun, Vol.3, No. 1 Maret 2016: 3843.

Novia \& Puspitasari. (2008). Faktor Resiko yang Mempengaruhi Kejadian Disminore Primer. Accessed on June 7, 2017 from http://journal.unair.ac.id/downloadfullpapers-Naskah\%204\%20(h96103).pdf.

Potter \& Perry. (2006). Buku Ajar Fundamental Keperawatan: Konsep, Proses, dan Praktik Edisi 4 Vol. 2. Jakarta: Penerbit Buku Kedokteran EGC.

Riyadhi, NF. (2014). Pengaruh Terapi Murattal Al-Qur'an terhadap Tingkat Kecemasan Pada Pasien Pre Operasi Di Rumah Sakit Umum Daerah (RSUD) Labuang Baji Provinsi Sulsel. Accessed on June 12, 2017 from http://repositori.uinalauddin.ac.id/6489/1/Nurul\%20Fuadi \%20Riyadhi.pdf.

Sari, Praditiana IP. (2015). Perbedaan Tingkat Nyeri Disminorea dengan Senam Disminorea, Murottal AlQur'an, dan Senam Disminorea kombinasi Murottal Al-Qur'an. Accessed on June 12, 2017 from http://thesis.umy.ac.id/datapublik/t530 76.pdf.

Sari, D., Nurdin, A. E., \& Defrin, D. (2015). Hubungan Stres dengan Kejadian
Dismenore Primer pada Mahasiswi

Pendidikan Dokter Fakultas

Kedokteran Universitas

Andalas. Jurnal Kesehatan

Andalas, 4(2).

Sigit, Prasetyo Nian. (2010). Konsep Dan Proses Keperawatan Nyeri.

Yogyakarta: Graha Ilmu.

Siswanto, dkk. (2011). Pengaruh Terapi

Suara Tartil Al-Qur'an Terhadap

Penurunan Tingkat Insomnia Pada

Lanjut Usia di Panti Tresna Wredha Muhammadiyah Kota Probolinggo.

Stuart, G.W., Sundeen, S.J. (1998). Keperawatan Jiwa. Jakarta: EGC.

Tamsuri, Anas. (2006). Konsep dan Penatalaksanaan Nyeri. Jakarta: EGC.

Azis, W., Nooryanto, M., \& Andarini, S. (2015). Terapi Murotal Al-Qur'an Surat Arrahman Meningkatkan Kadar $\beta$-Endorphin dan Menurunkan Intensitas Nyeri pada Ibu Bersalin Kala I Fase Aktif. Jurnal Kedokteran Brawijaya, 28(3), 213-216.

Wisudawati, E. R., Djuria, S. A., Erita, Puspitasari, P. I., \& Gunadi, A. (2014). Efektifitas Senam Dismenore dengan Teknik Relaksasi Terapi Murottal untuk Mengurangi Dismenore. Accessed on June 5, 2017 from http://www.umy.ac.id/\%E2\%80\%8Bs erem-quran-terbukti-turunkan-nyerihaid-disminore.html.

Yanti, (2011). Buku Ajar Kesehatan Reproduksi. Yogyakarta: Pustaka Rihana.

Cite This Article As: Septianingrum, Y., Hatmanti, N. M., Fitriasari, A. The Effect of Murottal Qur'an on Menstrual Pain in Nursing Student of Universitas Nahdlatul Ulama Surabaya. Nurse and Health: Jurnal Keperawatan 2019; 8(1): $8-15$. 